\title{
Probing the bioavailability of organically bound iron: a case study in the Synechococcus-rich waters of the Gulf of Aqaba
}

\author{
Hagar Lis ${ }^{1,2, *}$, Yeala Shaked ${ }^{1,2}$ \\ ${ }^{1}$ Interuniversity Institute for Marine Sciences in Eilat, POB 469, Eilat 88103, Israel \\ ${ }^{2}$ Hebrew University of Jerusalem, Institute of Earth Sciences, Edmond Safra campus - Givat Ram, Jerusalem 91904, Israel
}

\begin{abstract}
The bioavailability of organically chelated and ambient iron to phytoplankton in the Gulf of Aqaba was examined in 2 sets of grow-out incubations amended with major nutrients and increasing concentrations of the model organic ligand desferrioxamine B (DFB). Short-term uptake of pre-complexed ${ }^{55} \mathrm{FeDFB}$ was then conducted with the DFB-incubated natural populations. Since incubation communities were dominated by Synechococcus spp., short-term FeDFB uptake experiments with Synechococcus WH8102 cultures complemented the field study. The role of extracellular reduction in FeDFB acquisition was studied in accordance with the Fe(II)s model (Shaked et al. 2005) by applying large excesses of DFB. Ambient iron was found adequate in meeting natural phytoplankton iron demands in incubations containing major nutrients. A gradually increasing iron-stress response was observed as DFB concentration increased and titrated out ambient iron. Nevertheless, both natural phytoplankton and Synechococcus WH8102 cultures were able to acquire DFB-bound iron. FeDFB uptake rates were inhibited by large excesses of DFB. This may indicate the operation of an extracellular reduction step in the acquisition of FeDFB by natural populations in the Gulf of Aqaba and Synechococcus WH8102.
\end{abstract}

KEY WORDS: Iron acquisition · Extracellular reduction · Organic complexation · Desferrioxamine B (DFB) $\cdot$ Synechococcus · Marine cyanobacteria $\cdot$ Gulf of Aqaba

\section{INTRODUCTION}

The biogeochemical cycling of iron $(\mathrm{Fe})$ in the ocean is essential to marine productivity. Iron is not only inseparably linked to the global carbon cycle, but may have also played an important role in carbon cycle variations throughout the geological history of the Earth (Martin et al. 1990). The bioavailability of iron to marine phytoplankton lies at the heart of these issues and bioavailability, in turn, is largely a question of iron speciation on the one hand and physiological uptake systems on the other. At the circumneutral $\mathrm{pH}$ of ocean waters, iron has an extremely low solubility, and over $99 \%$ of dissolved Fe is predicted to be complexed by organic ligands with very high stability constants with respect to iron (Rue \& Bruland 1995). Organic Fe- ligands thus buffer extremely low inorganic Fe (i.e. unchelated $\mathrm{Fe}$ or $\mathrm{Fe}^{\prime}$ ) concentrations in the ocean. The growth of phytoplankton (even iron-limited growth) cannot be explained in many ocean regions when taking $\mathrm{Fe}^{\prime}$ as a sole Fe source into account, as suggested by the conventional Fe' model (Hudson \& Morel 1990, Sunda \& Huntsman 1995). While the verdict regarding the importance of photochemistry in generating highly bioavailable transient $\mathrm{Fe}^{\prime}$ remains unknown (Barbeau 2006, Morel et al. 2008), understanding how different phytoplankton taxa access organically bound iron will greatly assist in defining iron bioavailability to marine phytoplankton.

The marine environment consists of a variety of organic Fe-compounds, some of which display stability constants with regard to ferric iron similar to those of 
siderophores (Rue \& Bruland 1995). Siderophores are Fe-specific, low molecular weight compounds released by $\mathrm{Fe}$-limited microorganisms to enhance iron acquisition (Winkelmann 2002). Siderophore production as a response to $\mathrm{Fe}$ stress has also been reported for several freshwater and marine microorganisms (Wilhelm \& Trick 1994, Granger \& Price 1999, Martinez et al. 2001). Therefore, siderophores isolated from a variety of Fe-limited organisms have been widely used in laboratory and field studies to simulate organic ligands in the marine environment. One such commercially available siderophore is desferrioxamine B (DFB) produced by the terrestrial fungus Streptomyces pilosus (Winkelmann 1991); this is a trihydroxamate hexadentate siderophore with an extremely high conditional stability constant with regard to Fe(III) in seawater (Hudson et al. 1992).

Despite its being a xenosiderophore in the marine environment, we believe that DFB is a relevant Feligand model for a number of reasons. Firstly, DFBlike compounds have been isolated from the ocean (Martinez et al. 2001, Mawji et al. 2008). Secondly, many marine siderophores, like DFB, are characterized by hydroxamate moieties (Mawji et al. 2008). Lastly, phytoplankton do not necessarily use organism-specific siderophores and siderophore 'piracy' may play an important role in iron nutrition of marine microorganisms (Granger \& Price 1999). DFB is also a very convenient Fe-ligand, characterized by a high affinity for Fe (buffering no $\mathrm{Fe}^{\prime}$ when applied at equimolar ratios), fast binding (rapidly exchanges the natural Fe pools) and photo-inertness (no transient $\mathrm{Fe}^{\prime}$ ) and can therefore address the uptake of organically bound iron exclusively. While several marine organisms, both prokaryotic and eukaryotic, have been shown to acquire DFB-bound iron (FeDFB; Allnutt \& Bonner 1987a, Soria-Dengg \& Horstmann 1995, Maldonado \& Price 2001, Shaked et al. 2005, Chen \& Wang 2008), its application in representing naturally occurring organically bound iron has been complicated by the fact that DFB has been widely used to bind iron and induce iron limitation in different oceanic regions and culture based experiments (Wells et al. 1994, Wells 1999, Eldridge et al. 2004).

In many of the studies which report FeDFB to be unavailable, DFB was added in large excess to ambient iron concentrations (Wells 1999, Eldridge et al. 2004). This was done to accelerate the exchange of $\mathrm{Fe}$ from the ambient Fe-complexes to DFB. While contradicting results regarding the bioavailability of a specific compound can be easily settled by considering differences in phytoplankton composition and/or ironnutrition status of cells, we seek to explain this apparent discrepancy mechanistically. According to a new uptake model, the Fe(II)s model (Shaked et al. 2005), the strong inhibitory effect of excess DFB additions on phytoplankton growth and uptake is not only due to the induced change in iron speciation, but also due to DFB's ability to compete with cells for an unchelated iron intermediate formed at the cell surface during extracellular reduction.

This recently published kinetic uptake model (Shaked et al. 2005) — the Fe(II)s model - was formulated to reconcile existing knowledge on iron uptake with new evidence supporting a reductive step in the acquisition of organically bound iron (Fig. 1). Simply put, the Fe(II)s model proposes that all iron species (inorganic as well as organic) undergo extracellular
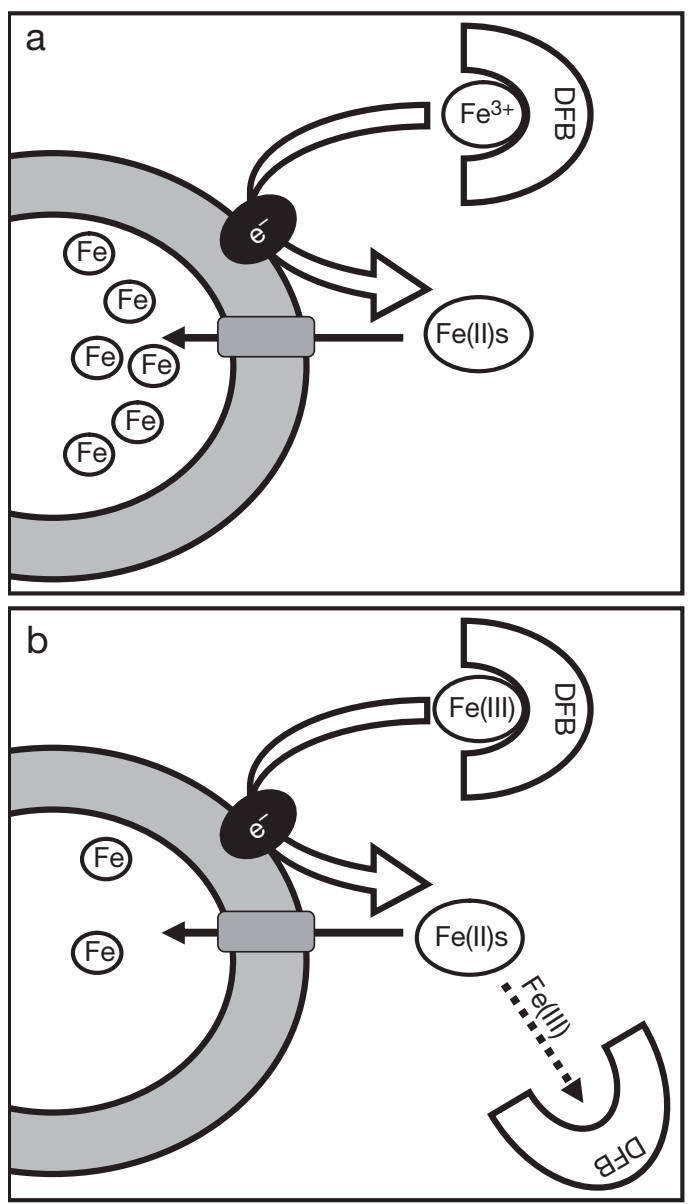

Fig. 1. Schematic illustration of the Fe(II)s model adapted from Shaked et al. (2005). (a) Extracellular reductases reduce ferric iron bound to organic ligands such as desferrioxamine B (DFB) causing Fe(II) to leave the organic complex. Intermediate Fe(II) formed at the cell surface is transported across the membrane by specific transporters, probably following its reoxidation. The Fe(II) intermediate may undergo oxidation and/or re-complexation during these stages. (b) Excess free Fe-ligand present in the medium competes with the cell over the free Fe (ferrous or ferric) near the cell surface, thereby inhibiting uptake and growth rates 
reduction prior to transport. This involves the formation of an intermediate Fe(II) species at the cell surface (Fig. 1a) which may then enter the cell or be subject to complexation by free Fe-binding ligands in the medium (probably following its re-oxidation; Fig. 1b). Therefore, free Fe-ligand in the medium can compete with the cells for unchelated inorganic Fe species at the cell surface, be they Fe(II) or Fe(III), and inhibit the rate of uptake/growth. The efficiency of the reductive mechanism is thus highly dependent on relative concentrations of excess organic ligands in solution and cell surface Fe transporters competing for Fe' (Maldonado \& Price 2001). The Fe(II)s model has been successfully applied to eukaryotic lab cultures, although its applicability to prokaryotes and natural samples remains unknown.

In this study we use the Fe (II)s uptake model as a framework within which to probe the iron acquisition strategies of phytoplankton growing in the Gulf of Aqaba, using DFB as a model organic ligand. By coupling grow-out incubations with short-term iron uptake experiments, we explored the bioavailability of FeDFB to natural phytoplankton and its mechanism of uptake. These experiments also facilitated the examination of naturally occurring iron bioavailability. A parallel study with laboratory cultures of Synechococcus spp., the dominant phytoplankton species in the Gulf at the time of our study, was conducted to support field findings.

\section{STUDY AREA}

The Gulf of Aqaba, the northernmost extension of the Red Sea, is surrounded by Israel, Jordan, Egypt and Saudi Arabia (for location map see Fig. 1 in Berman-Frank et al. 2009; this Special Issue, p. 110). Since the Gulf is not characteristic of other coastal settings, we felt it prudent to include some background information regarding this environment. The Gulf of Aqaba is 180 $\mathrm{km}$ long, narrow (6 to $25 \mathrm{~km}$ ) and deep (max. $1.8 \mathrm{~km}$ ). It is semi-enclosed by deserts where the hot, arid climate dictates conditions of sparse vegetation, negligible precipitation $\left(\sim 3 \mathrm{~cm} \mathrm{yr}^{-1}\right)$ and runoff as well as high evaporation rates $\left(\sim 180 \mathrm{~cm} \mathrm{yr}^{-1}\right.$, Ben-Sasson et al. 2009). The Gulf is subject to distinct seasonal fluctuations. Throughout the summer the water column is thermally stratified and surface concentrations of major nutrients are exceedingly low $\left(\mathrm{NO}_{3}<200 \mathrm{nM}, \mathrm{PO}_{4}<60 \mathrm{nM}\right.$, Genin et al. 1995). In winter, deep convective mixing replenishes the nutrients at the surface (Fig. 2a; Genin et al. 1995) until the onset of stratification during the spring, when surface nutrient concentrations rapidly wane as they are consumed by phytoplankton blooms (Fig. 2b). The Gulf waters are oligotrophic, with maximum chlorophyll a (chl a) concentrations of $0.75 \mu \mathrm{g}$ $\mathrm{l}^{-1}$ during the spring and minimum concentrations of $0.25 \mathrm{\mu g} \mathrm{l}^{-1}$ in midsummer (Labiosa et al. 2003). The phytoplankton community is dominated by relatively small species $(<8 \mu \mathrm{m})$ where the cyanobacteria, Synechococcus spp. and Prochlorococcus spp., dominate in the spring and summer respectively, while picoeukaryotic species are more abundant during winter mixing events (Lindell \& Post 1995). In addition, DOC concentrations are relatively low, i.e. 70 to $90 \mu \mathrm{M}$, typical of open ocean waters rather than of coastal environments (Yahel et al. 2003).

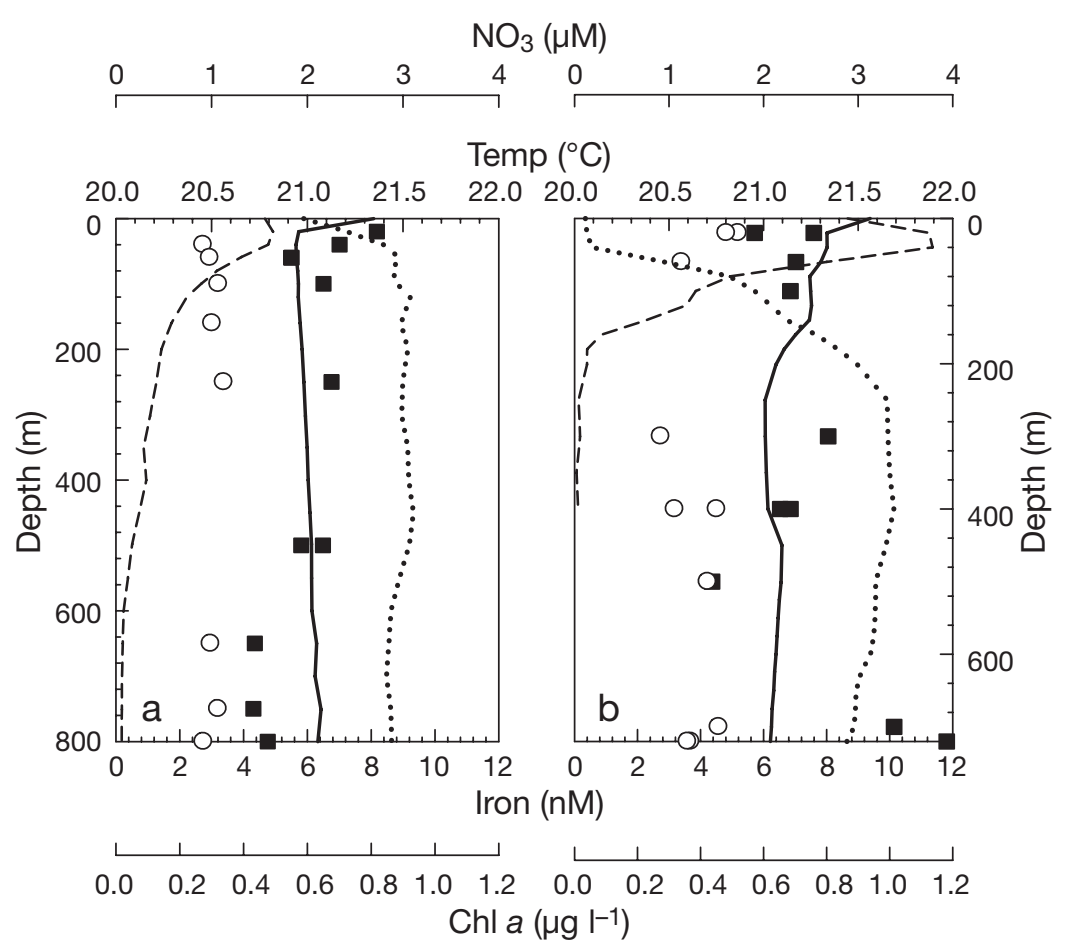

Fig. 2. Water column characteristics in the open waters of the northern Gulf of Aqaba during the study period (Spring 2008). Nitrate: dotted line; chlorophyll a (chl a): dashed line; temperature: solid line; total iron: black squares; dissolved iron: empty circles. (a) March 2008. Temperature and chl a profiles indicate that stratification has just commenced. Surface major nutrient concentrations are relatively high (only nitrate is shown). Total $\left(\mathrm{Fe}_{\text {total }}\right)$ and dissolved $(<0.2 \mu \mathrm{m}$, $\mathrm{Fe}_{\text {diss }}$ ) iron are evenly distributed throughout the water column. (b) April 2008. Temperature profile reveals the onset of stable stratification. A spring bloom event is evident from the depleted nitrate concentrations in surface waters and high chl a concentrations. Iron profiles remain evenly distributed throughout the water column with minor shifts in concentration 
Dissolved iron $(<0.2 \mu \mathrm{m})\left(\mathrm{Fe}_{\text {diss }}\right)$ concentrations are high all year round and range from 2 to $6 \mathrm{nM}$ (Fig. 2, Shaked 2008). Total iron $\left(\mathrm{Fe}_{\text {total }}\right)$ concentrations in the upper water column are only slightly higher than $\mathrm{Fe}_{\text {diss }}$ and range from 3 to $10 \mathrm{nM}$ (Fig. 2, Shaked 2008). Elevated total iron concentrations (10 to $50 \mathrm{nM}$ ) were recorded in the lower water column during stratification (Y. Shaked unpubl.). The high iron concentrations in Gulf waters are thought to originate from sediment resuspension and atmospheric deposition (Chase et al. 2006, Shaked 2008)

\section{MATERIALS AND METHODS}

Trace metal clean methods. All experimental manipulations were carried out according to stringent trace metal clean protocols in a clean room facility or under positive pressure high efficiency particulate air (HEPA) filters. All plastic ware used for cultures, incubations and Fe sampling and measurements were soaked in soap for $48 \mathrm{~h}$, rinsed in deionised water (DI), followed by a $48 \mathrm{~h}$ soak in $10 \% \mathrm{HCl}$ and a final thorough wash in Milli-Q water. After $\mathrm{HCl}$ treatment, culture bottles were filled with Milli-Q water amended with EDTA and stored. Incubation carboys were rinsed with seawater 3 times before being filled. Solutions were prepared using 18.2 M $\Omega$.cm Milli-Q water and analytical grade salts. For trace metal clean methods employed during total and dissolved iron sampling and analysis see Shaked (2008).

Iron measurements. Iron sampling and analysis protocols are outlined in Shaked (2008). Briefly, samples were acidified with distilled $\mathrm{HCl}$ to $\mathrm{pH} \sim 1.7$ and kept for 6 mo prior to analysis according to the flow injection analysis (FIA) technique of Lannuzel et al. (2006). This technique involves a reduction step with sulfite, followed by direct measurement of Fe(II) in the FeLume system with the chemiluminescent reagent luminol.

Grow-out incubations. Two sets of grow-out experiments were carried out - one during March 2008 and the other during the 8th GAP (Group for Aquatic Primary Productivity) workshop in April 2008. Water samples for incubations were manually collected $50 \mathrm{~m}$ off the coast of the Interuniversity Institute of Eilat, Israel. Near surface water was collected in acid-washed 51 containers and dispensed into trace-metal cleaned 101 carboys. Since the dominant grazers in the Gulf of Aqaba are micrograzers (Sommer et al. 2002) comparable in size to picoeukaryotes, we did not prefilter water samples. Carboys were then taken back to the lab, weighed out to 81 each in a portable laminar hood, supplemented with nutrients and DFB (see below) and incubated for 2 to $3 \mathrm{~d}$ in a shaded (50 to $60 \%$ ambient light) pool through which surface seawater was contin- uously circulated. Sub-samples for different measurements were taken collectively during the early morning and evening.

The experimental designs for March and April are laid out in Table 1. To ensure phytoplankton were free of major nutrient stress, all incubation carboys, with the exception of no-nutrient controls, were amended with nutrients (Table 1a, Carboys 2 to 5; Table 1b, Carboys 3 to 13). Nutrient additions consisted of a $4 \mu \mathrm{M}$ nitrate/ammonium equimolar mix $\left(\mathrm{NaNO}_{3} / \mathrm{NH}_{4} \mathrm{Cl}\right.$, Merck, analytical grade) and $0.6 \mu \mathrm{M}$ phosphate $\left(\mathrm{NaH}_{2} \mathrm{PO}_{4} \cdot \mathrm{H}_{2} \mathrm{O}\right.$, Merck, analytical grade). A range of DFB (desferrioxamine mesylate, Calbiochem cat\#252750) concentrations was applied in order to probe 2 distinctive questions: (1) bioavailability of FeDFB at the lower DFB concentration range (600 pM to $20 \mathrm{nM}$ ); and (2) the mechanism of iron acquisition from the FeDFB complex at the upper range (50 $\mathrm{nM}$ to $1 \mu \mathrm{M})$. The iron nutrition status of natural and DFB-exposed populations was evaluated by the addition of precomplexed FeEDTA (1:1.1) (EDTA $\mathrm{C}_{10} \mathrm{H}_{14} \mathrm{~N}_{2} \mathrm{Na}_{2} \mathrm{O}_{8} \cdot 2 \mathrm{H}_{2} \mathrm{O}$, Titriplex III, Merck) at the start or during the course of the incubation (Table 1b, Carboys 1, 2 and 6). FeEDTA has been shown to be a readily available iron source in many field and culture studies due to the fast dissociation rate of iron from the complex, buffering a large pool of easily accessible unchelated iron (Fe') (Hudson \& Morel 1990).

Chl a measurements. Total chl a was determined from individually weighed samples filtered onto a GF/F filter (Whatman). Chl a was quantified with a Turner Design, Model AU-10 fluorometer according to the acidification method (Parsons et al. 1985) after $24 \mathrm{~h}$ dark extraction in $90 \%$ acetone at $4^{\circ} \mathrm{C}$.

Flow cytometry. Aliquots $(1.5 \mathrm{ml})$ were fixed with $1 \%$ glutaraldehyde, quickly frozen in liquid nitrogen and kept at $-70^{\circ} \mathrm{C}$ until analysis on a FACS instrument (FACScan, Becton Dickinson). Taxonomic discrimination was made on the basis of cell-side scatter and forward scatter (a proxy of cell size), orange fluorescence of phycoerythrin, and red fluorescence of chlorophyll (Partensky et al. 1996). All samples for cell counts were run with $0.95 \mu \mathrm{m}$ YG Polysciences beads. Non-photosynthetic bacteria were analyzed following staining with the nucleic acid dye SYBR Green I (Molecular Probes, S-7567, Marie et al. 1997). Data processing was performed using the Windows based programme CYTOWIN (Vaulot 1989) while contour plots were made using WinMDI version 2.5 software (copyright J. Trotter 1997, available at http://facs.scripps.edu).

Fast repetition rate fluorometry. Photochemical quantum efficiency, defined as the ratio of variable fluorescence to maximal fluorescence $\left(F_{\mathrm{v}}: F_{\mathrm{m}}\right)$, was measured by a fast repetition rate fluorometer (FIRe Fluo- 
Table 1. Grow-out incubations plan for (a) March and (b) April 2008 listing nutrient (P and N) and desferrioxamine B (DFB) additions as well as the rationale underlying each incubation. Nutrients and/or DFB added $(+)$ or not added $(-)$. $t_{0}$ : time 0

\begin{tabular}{|c|c|c|c|c|}
\hline Incubation no. & Treatment & Nutrients added & DFB additions & Tested hypothesis \\
\hline \multicolumn{5}{|l|}{ (a) March 2008} \\
\hline 1 & No nutrient control & - & - & Major nutrients limit growth \\
\hline 2 & Nutrient only control & + & - & Major nutrients limit growth \\
\hline 3 & Low DFB addition & + & $600 \mathrm{pM}$ & $\begin{array}{l}\text { Increased binding of ambient Fe by } \\
\text { DFB modifies its bioavailability }\end{array}$ \\
\hline 4 & Intermediate DFB addition & + & $10 \mathrm{nM}$ & $\begin{array}{l}\text { Increased binding of ambient Fe by } \\
\text { DFB modifies its bioavailability }\end{array}$ \\
\hline 5 & High DFB addition & + & $1 \mu \mathrm{M}$ & $\begin{array}{l}\text { Excess DFB hinders growth due to } \\
\text { competition over unchelated iron }\end{array}$ \\
\hline \multicolumn{5}{|l|}{ (b) April 2008} \\
\hline 1 & No nutrient control & - & $\begin{array}{l}150 \text { nM FeEDTA } \\
\text { added at } t_{0}\end{array}$ & $\begin{array}{l}\text { Major nutrients rather than } \\
\text { iron limit growth }\end{array}$ \\
\hline 2 & No nutrient control & - & $\begin{array}{l}150 \mathrm{nM} \text { FeEDTA } \\
\text { added at } 33 \mathrm{~h}\end{array}$ & $\begin{array}{l}\text { Major nutrients rather than } \\
\text { iron limit growth }\end{array}$ \\
\hline 3 & Nutrient only control & + & - & Major nutrients limit growth \\
\hline 4 & Low DFB addition & + & $3 \mathrm{nM}$ & $\begin{array}{l}\text { Increased binding of ambient Fe } \\
\text { by DFB modifies its bioavailability }\end{array}$ \\
\hline 5 & Intermediate DFB addition & + & $20 \mathrm{nM}$ & $\begin{array}{l}\text { Increased binding of ambient Fe } \\
\text { by DFB modifies its bioavailability }\end{array}$ \\
\hline 6 & Intermediate DFB addition & + & $50 \mathrm{nM}$ & $\begin{array}{l}\text { Excess DFB hinders growth due to } \\
\text { competition over unchelated iron }\end{array}$ \\
\hline 7 & Intermediate DFB addition & 50 & $\begin{array}{l}50 \mathrm{nM}, 150 \mathrm{nM} \text { FeEDTA } \\
\text { added at } 33 \mathrm{~h}\end{array}$ & $\begin{array}{l}\text { Addition of excess, readily available } \\
\text { Fe alleviates DFB-induced stress }\end{array}$ \\
\hline $8-13$ & High DFB addition & + & $1 \mu \mathrm{M}$ & $\begin{array}{l}\text { Excess DFB hinders growth due to } \\
\text { competition over unchelated iron }\end{array}$ \\
\hline
\end{tabular}

rometer system, SAtlantic). On the third morning (time $[t]=45 \mathrm{~h}$ ) of the April incubation all treatments were sampled collectively and dark adapted at room temperature for at least 30 min prior to measurement. Filtered seawater $(0.2 \mu \mathrm{m})$ was run as a blank. Data was processed in the Matlab based programme Fireworx 0.9.2. (copyright A. Barnett 2007, available at http:// sourceforge.net/projects/fireworx).

Short-term iron uptake. All uptake experiments were conducted within acid-cleaned polycarbonate bottles. The experiment medium consisted of $\mathrm{pH}$ adjusted ( $\mathrm{pH} \sim 8$ to 8.2) Synthetic Ocean Water (SOW) prepared according to the Aquil salt mix protocol as outlined by Morel et al. (1979). ${ }^{55} \mathrm{Fe}$ (Perkin Elmer, hot only at specific activity of 93.64 or $88.74 \mathrm{mCi} \mathrm{mg}^{-1}$ in natural population and culture uptake experiments respectively) was precomplexed with DFB at a low $\mathrm{pH}$, then gradually titrated to $\mathrm{pH} 8$ to avoid the precipitation of iron, and allowed to equilibrate overnight. Fe:DFB ratio was 1:1.1 for experiments performed with natural populations and 1:2 for culture uptake experiments. To study the effect of excess Fe-ligand on iron uptake rates, $1 \mu \mathrm{M}$ DFB was added to the uptake medium prior to the start of the experiment. In addi- tion, $200 \mu \mathrm{M}$ of the Fe(II)-specific ligand bathophenanthroline disolfonic acid disodium salt (BPDS, Sigma) was also applied to a probe specifically for a ferrous iron intermediate.

Cells for uptake experiments were gently filtered ( $<100 \mathrm{~mm} \mathrm{Hg}$ ) onto acid-washed polycarbonate or Supor membrane filters $(0.45 \mu \mathrm{m})$, thoroughly rinsed with SOW, and resuspended in a $15 \mathrm{ml}$ tube containing SOW. A small volume of this resuspension was taken for chl $a$ and flow cytometry (FACS) analysis, and the remainder was distributed between the FeDFB and the FeDFB $+1 \mu \mathrm{M}$ treatments and kept in the dark. At various times during the 7 to $13 \mathrm{~h}$ uptake experiment, weighted volumes of the experiment medium were filtered onto a $0.2 \mu \mathrm{m}$ pore-size polycarbonate filter, rinsed with SOW, washed with Ti-citrate-EDTA reagent (Hudson \& Morel 1989) for $5 \mathrm{~min}$ and then rinsed again with SOW. Duplicate samples were processed at most time points. The filters were retained for measurement of radioactivity in a Beckman scintillation counter with Quicksafe A scintillation liquid (Zinsser Analytic). Intracellular iron was calculated from the average specific activity (activity of the medium divided by the total iron added). 
Synechococcus WH8102 cultures. Since our data pointed to Synechococcus spp. as the dominant species in incubation populations and uptake experiments, we decided to support field observations by investigating the FeDFB uptake strategies of Synechococcus cultures. To this end, Synechococcus strain WH8102, an open ocean Sargasso Sea isolate bearing genetic similarity to certain Synechococcus spp in the Gulf of Aqaba (Penno et al. 2006) was chosen. Synechococcus WH8102 cultures were grown in trace metal clean polycarbonate erlenmyers fitted with a breathable cap, at $24^{\circ} \mathrm{C}$ and under continuous light $\left(50 \mu \mathrm{mol}\right.$ quanta $\mathrm{m}^{-2}$ $\mathrm{s}^{-1}$ ). Experimental culture medium was based on the AMP1 medium (Moore et al. 2007) made up of synthetic seawater, buffered with $20 \mu \mathrm{M}$ EDTA and an ammonium $\mathrm{N}$ source. To obtain high biomass for uptake experiments, cultures were grown with 300 nM FeEDTA and iron limitation was then induced by adding $1 \mu \mathrm{M}$ DFB 48 $\mathrm{h}$ prior to the experiment. Growth was monitored by measuring absorbance at $750 \mathrm{~nm}$ (a proxy for cell number) (Duke et al. 1989) measured with a CARY 50 UV/Vis spectrophotometer.

Other methods. Major nutrients (nitrate, phosphate and silica, i.e. silicic acid) in the water (Fig. 2) and grow-out incubations were analyzed by the National Monitoring Program (NMP) team, using colorimetric methods described by Hansen \& Koroleff (1999), modified for a Flow Injection Autoanalyzer (FIA, Lachat Instruments Model QuickChem 8000) with a precision of $\pm 0.02 \mu \mathrm{mol} \mathrm{l}{ }^{-1}$. Analysis methods are outlined on the NMP official website (www.iui-eilat.ac.il/NMP/).

\section{RESULTS \\ Incubations with natural phytoplankton assemblages}

\section{Effect of increasing DFB additions on phytoplankton growth}

Extracted chl a was used as an indicator of bulk autotrophic community status. For clarity we present the change in chl a $(\Delta \mathrm{chl}$ a) after $47 \mathrm{~h}$ (March experiment, Fig. 3a,b) or $33 \mathrm{~h}$
(April experiment, Fig. 3c,d). Increase in $\Delta \mathrm{chl}$ a values is interpreted as a growth response (Fig. 3). A complete data set of chl a measurements is given in the supplementary data (Fig. S1, available as supplementary material at www.int-res.com/suppl/a056p241 _app.pdf).

Maximal growth $\left(\Delta \mathrm{chl}_{\max }\right)$ was observed in the nutrient-only incubations, whereas no growth (April) or minimal growth (March) was obtained in the nonamended incubations (Fig. 3). This indicates that the phytoplankton populations in our controls with no major
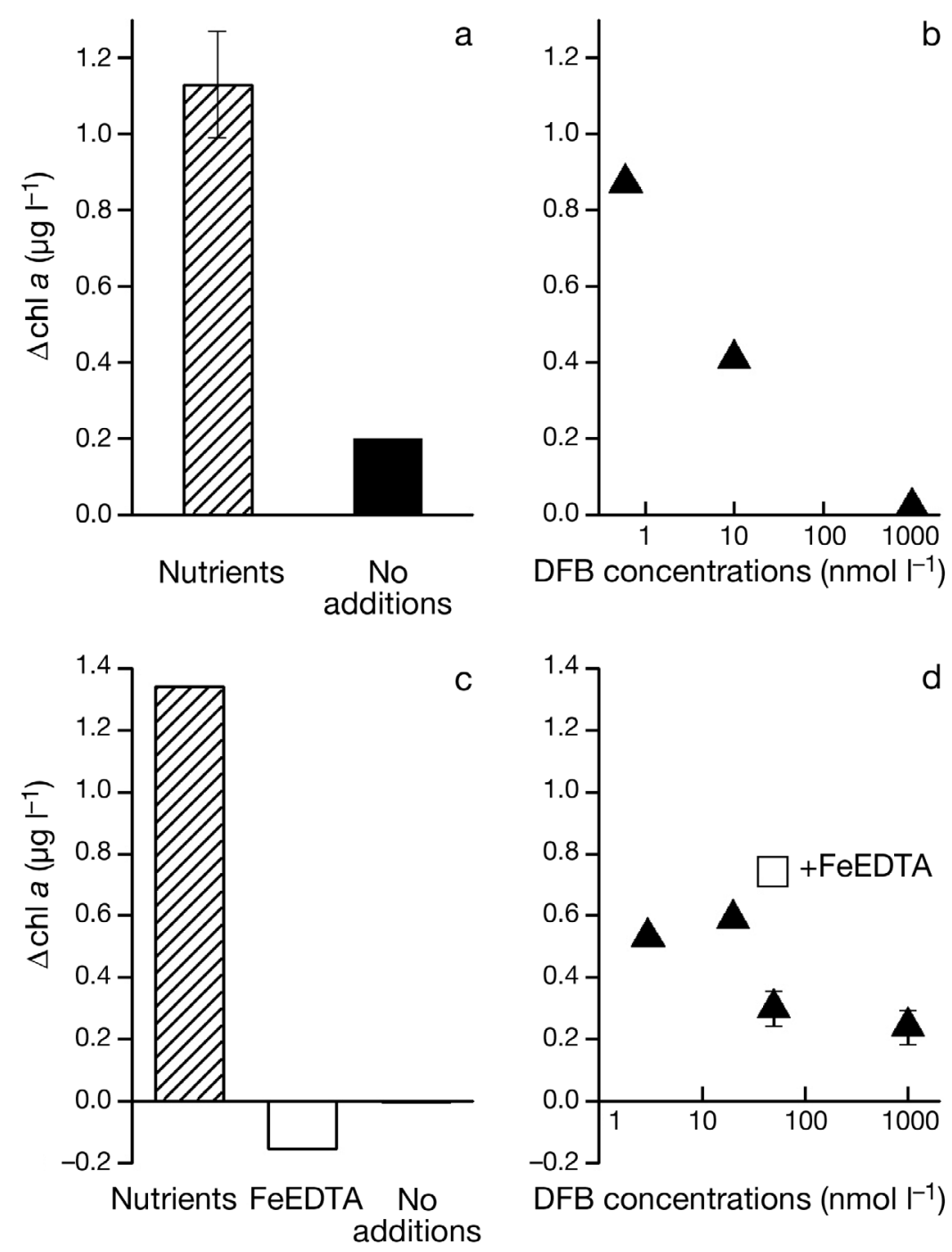

DFB concentrations $(\mathrm{nmol} \mathrm{I-1})$

Fig. 3. Growth response in the grow-out incubations as measured by the change in chlorophyll a ( $\mathrm{chl}$ a) concentrations $\left(\Delta \mathrm{chl} a\right.$, in $\left.\mu g \mathrm{l}^{-1}\right)$ from the start of the incubation (time, $t=0)$ to its end $(t=47 \mathrm{~h}$ and $33 \mathrm{~h}$ for March and April, respectively). (a,b) March 2008, (c,d) April 2008. (a,c) Control incubation carboys that received no desferrioxamine B (DFB) additions represented by bar graphs. (b,d) All DFB-containing incubations shown were enriched with major nutrients. Note that the $y$-axis in both panels is the same. The white square in (d) indicates $\Delta$ chl $a$ after the addition of FeEDTA ( $20 \mathrm{~h}$ post-addition) to Incubation 6 (50 nM DFB + nutrient). Error bars are SD on duplicate treatments. DFB concentration is represented on a logarithmic scale 
nutrient additions were limited by major nutrients $(\mathrm{N}$ and P). Co-limitation by nitrogen and phosphorus has been recurrently observed in grow-out incubations conducted in the Gulf of Aqaba (Al-Qutob et al. 2002, Suggett et al. 2009, this Special Issue). Our incubations took place in the dynamic spring period, starting in March where major nutrients are still present at the surface (Fig. 2a), and ending in April where the major nutrients are mostly consumed by phytoplankton (Fig. 2b). This difference is reflected in the moderate growth of the nonutrient control in March as opposed to no growth at all in the April no-nutrient control (Fig. 3).

DFB additions, from $\mathrm{pM}$ to $\mu \mathrm{M}$ level, resulted in progressively decreasing $\Delta$ chl a values as compared to nutrient-only controls (Fig. 3). It must be noted that despite the obvious inhibitory effect of DFB, a positive $\Delta$ chl $a$, indicative of growth was observed in all DFB amended treatments (Fig. 3). To verify that the inhibitory effect of DFB resulted solely from its binding of iron, $150 \mathrm{nM}$ FeEDTA was added to a DFB containing incubation carboy (nutrients + $50 \mathrm{nM} \mathrm{DFB}$, Table $1 \mathrm{~b}$ ) at $33 \mathrm{~h}$. A significant increase in chl a was observed in this treatment as the iron limitation imposed by DFB was alleviated (Fig. 3d; white square).

Effect of increasing DFB additions on the photochemical quantum efficiency of cells

Whereas chl a change allows the examination of bulk autotrophic community response to DFB additions, fast repetition rate fluorometry (FRRF) measurements provide a closer look into the physiological status of the cells. Here we report photochemical quantum efficiency $\left(F_{\mathrm{v}}: F_{\mathrm{m}}\right)-\mathrm{a}$ ratio often used as an indication of nutrient stress, be it iron or any other nutrient (Behrenfeld \& Kolber 1999). $F_{\mathrm{v}}: F_{\mathrm{m}}$ values taken from the April incubation echo the trend seen in $\Delta \mathrm{chl}$ a data, with highest values for the nutrient-only control followed by progressively lower values as DFB concentration increases (Fig. 4). High $F_{\mathrm{v}}: F_{\mathrm{m}}$ values in nutrientonly controls were expected, considering our nutrient enrichment, absence of DFB and relatively high concentration of $\mathrm{Fe}$ in the waters at the start of our incubations: $\mathrm{Fe}_{\text {total }}=10.5 \pm 2.7 \mathrm{nM}$ and $\mathrm{Fe}_{\text {diss }}=3.6 \pm 1.3 \mathrm{nM}$. Low $F_{\mathrm{v}}: F_{\mathrm{m}}$ ratios were observed in treatments without major nutrient enrichment despite the presence of FeEDTA, reaffirming that major nutrients are in short supply rather than iron. The $F_{\mathrm{v}}: F_{\mathrm{m}}$ ratio is a measure of general nutrient stress and had we not supplemented the DFB incubations with major nutrients, we would have been unable to tease major nutrient stress apart from iron stress response. Iron stress induced by DFB was also evident from a marked increase in $F_{\mathrm{v}}: F_{\mathrm{m}} 24 \mathrm{~h}$ after FeEDTA was added to the nutrients + $50 \mathrm{nM}$ DFB incubation carboy (Fig. 4b, white square). The increase in $F_{\mathrm{v}}: F_{\mathrm{m}}$ was accompanied by an increase in chl a (Fig. $3 \mathrm{~d}$; white square). Photochemical quantum efficiency measurements of incubation populations thus indicate that phytoplankton in the Gulf of Aqaba are not iron limited but that DFB addition induces limitation, even when added at low concentrations.

\section{Flow cytometry data}

Flow cytometry counts of water samples taken at the start of both incubations show Synechococcus spp. to be numerically dominant at $10^{5}$ cell $\mathrm{ml}^{-1}$. Picoeukaryotes $(<8 \mu \mathrm{m})$ were less dominant $\left(\sim 10^{4}\right)$, but due to their larger size (1 to $2 \mu \mathrm{m}$ compared to $0.9-1.2 \mu \mathrm{m}$ for Synechococcus) they account for about half of the observed chl a. Non-photosynthetic bacteria counts averaged at $10^{6} \mathrm{cell} \mathrm{ml}^{-1}$. The 2 major autotrophic phytoplankton groups - Synechococcus and picoeukaryotes-responded differently to the addition of DFB, as demonstrated by cell density contour maps of FACS samples taken $22 \mathrm{~h}$ into the April incubations (Fig. 5). Picoeukaryote relative concentrations taper off
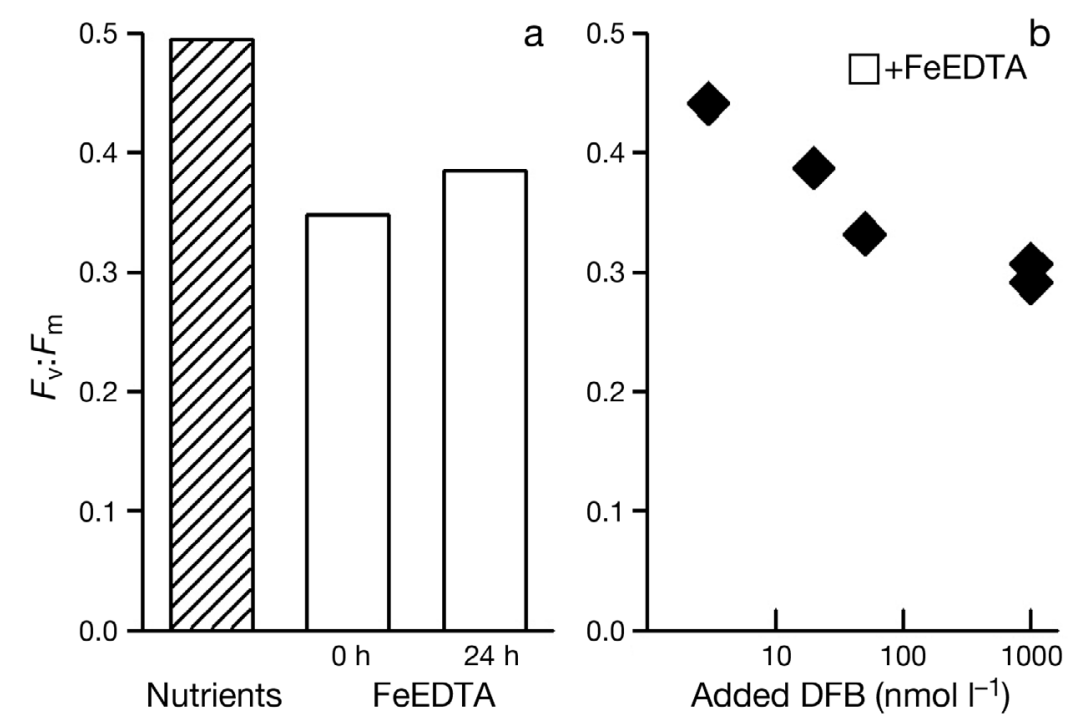

Fig. 4. Photochemical quantum efficiency (variable fluorescence to maximal fluorescence, $\left.F_{\mathrm{v}}: F_{\mathrm{m}}\right) 45 \mathrm{~h}$ into the April experiment. (a) Bars: incubations without desferrioxamine B (DFB); (b) black diamonds: nutrient-enriched +DFB incubations. The white square in (b) is incubation 6 (nutrients + $50 \mathrm{nM} \mathrm{DFB}$ ) to which excess FeEDTA was added at time $(t)=33 \mathrm{~h}$. DFB concentration is represented on a logarithmic scale 

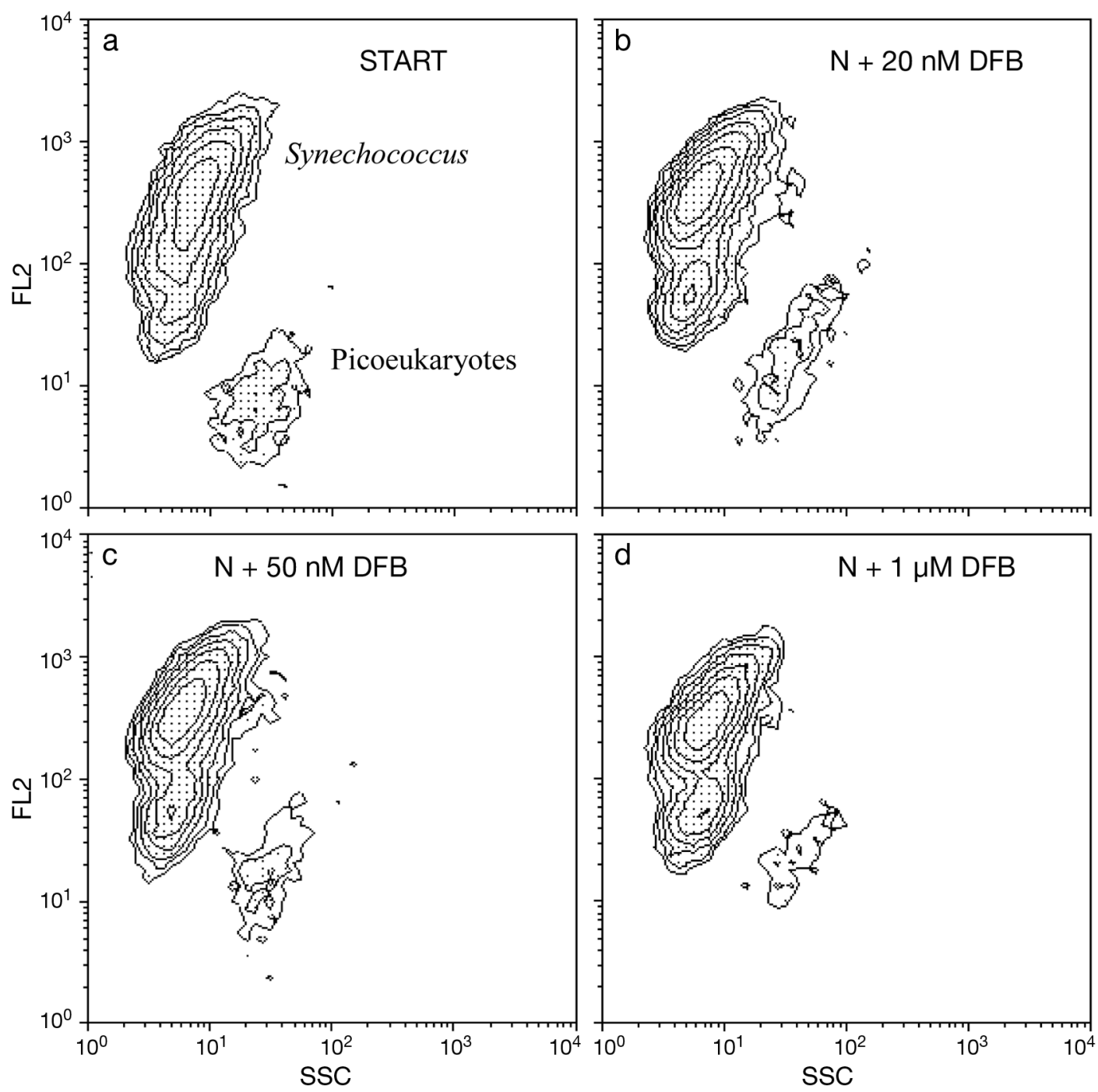

Fig. 5. Flow cytometry results of side scatter (SSC) versus orange fluorescence (FL2) show 2 distinctive gated populations within incubations: Synechococcus and picoeukaryote. (a) Initial populations in collected seawater (START) can be compared to (b,c,d) the same populations at varying desferrioxamine B (DFB) concentrations after a $22 \mathrm{~h}$ period. Dotted areas indicate greater cell density. Beads were not run in these samples and they were used for qualitative analysis alone

as DFB concentration increases, while Synechococcus concentrations remain unchanged or even slightly increase over the course of the incubation. Microscopic analysis revealed the presence of Chaetoceros spp. diatoms within our incubations, but their contribution to the total biomass was minor (E. Cappuzzo pers. comm.). Nutrient measurements showed no Si (silicic acid) drawdown in any of the incubations; if anything Si concentrations increased slightly in DFB (>3 nM) amended incubations carboys as well as in the noadditions control (Table S1, available as supplementary material at www.int-res.com/suppl/a056p241 _app.pdf). This indicates that no substantial diatom growth took place, whether it be the growth of larger diatom species such as Chaetoceros or smaller diatoms present in the picoeukaryote fraction of flow cytometry counts. We therefore believe Synechococcus spp. to be the main players in our experiments.

\section{Short-term FeDFB uptake by iron-limited grow-out incubation cells}

The growth response obtained in +DFB incubation carboys may merely reflect an incomplete exchange between the ambient iron pools and DFB or growth on intracellular iron stores rather than actual iron acquisition from the FeDFB complex. We therefore directly explored FeDFB acquisition in a short-term uptake experiment conducted in iron-free synthetic seawater 
with pre-complexed ${ }^{55} \mathrm{FeDFB}$. The cells used for these experiments were concentrated from incubations treated with $1 \mu \mathrm{M}$ DFB (Table 1) because they showed the highest degree of iron starvation (Fig. 4). A linear increase in intracellular ${ }^{55} \mathrm{Fe}$ was observed throughout both the March and April uptake experiments, clearly demonstrating that the cells were able to acquire iron from ${ }^{55}$ FeDFB (Fig. 6a April experiment). The measured chl a-normalized ${ }^{55} \mathrm{FeDFB}$ uptake rates for March and April were $6.4 \times 10^{-11}$ (for $140 \mathrm{nM}^{55} \mathrm{FeDFB}$ ) and $2.9 \times 10^{-11}$ (for $40 \mathrm{nM}{ }^{55} \mathrm{FeDFB}$ ) mol Fe $\mu g^{1}$ chl $a$ $\mathrm{d}^{-1}$, respectively. Despite the possible shift in the natural phytoplankton composition from March to April, the uptake rates measured during these 2 months agree within a factor of 2 when normalized to the same total Fe concentration.

In a parallel treatment, a large excess of DFB $(1 \mu \mathrm{M})$ was added to the uptake medium in order to test whether cells apply an extracellular reduction step to
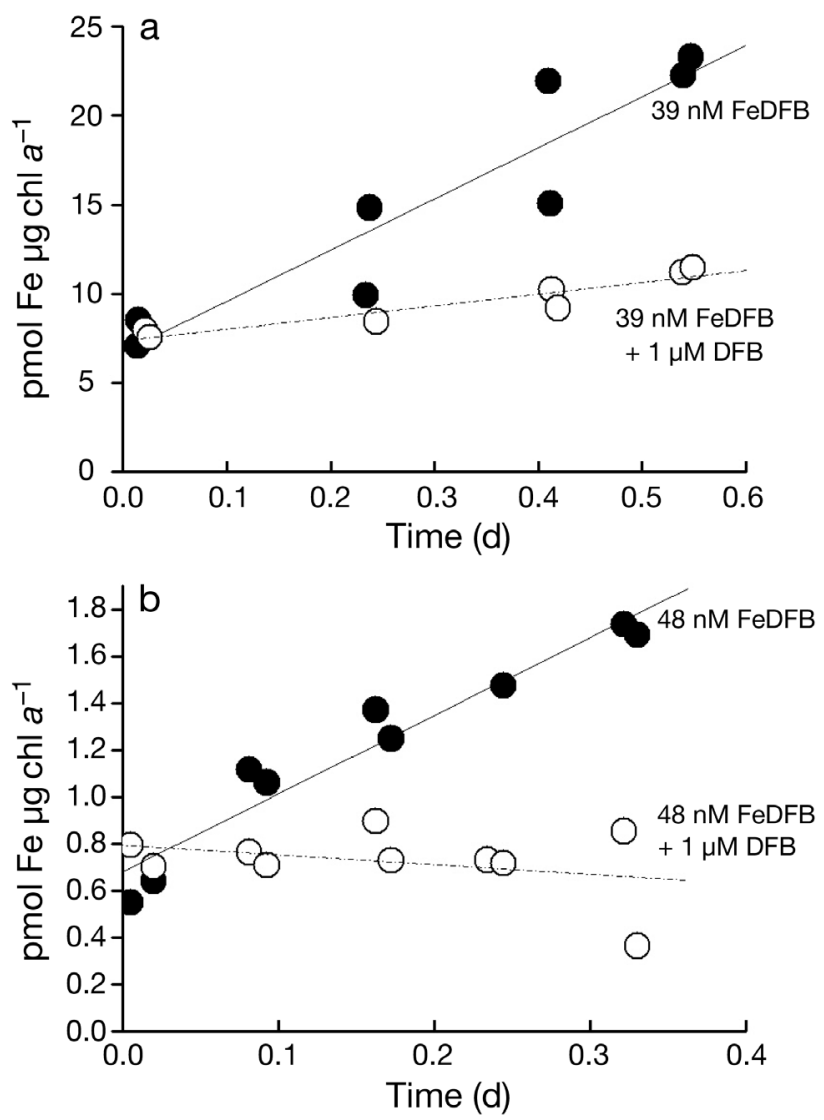

Fig. 6. Short-term ${ }^{55} \mathrm{Fe}$ desferrioxamine B $\left({ }^{55} \mathrm{FeDFB}\right)$ uptake. The experiment was preformed with pre-complexed ${ }^{55} \mathrm{FeDFB}$ in artificial seawater. (a) Uptake by iron-limited April incubation populations (nutrients $+1 \mu \mathrm{M} \mathrm{DFB}$; harvested after $33 \mathrm{~h}$ ). The same cells were used in both FeDFB and FeDFB $+1 \mu \mathrm{M}$ DFB uptake experiments. (b) Short-term uptake by ironstarved Synechococcus WH8102. Cells were Fe-limited by adding $1 \mu \mathrm{M}$ DFB to the growing medium $48 \mathrm{~h}$ prior to the uptake experiment release iron from the FeDFB complex. According to the Shaked et al. (2005) Fe(II)s model, a large excess of iron-binding ligands can effectively compete with the cells for the intermediate Fe species formed at the cell surface, thus inhibiting uptake rates of organically bound iron. A marked inhibition (77\%) of the FeDFB uptake rate was indeed observed in the presence of $1 \mu \mathrm{M}$ DFB (Fig. 6a).

\section{Synechococcus uptake}

Iron-limited Synechococcus WH8102 were able to acquire ${ }^{55} \mathrm{FeDFB}$ at a rate of $3.3 \times 10^{-13} \mathrm{~mol} \mathrm{Fe} \mathrm{\mu g}^{-1} \mathrm{chl}$ $\mathrm{a} \mathrm{d}^{-1}$ (Fig. 6b). The addition of excess DFB (1 $\left.\mu \mathrm{M}\right)$ inhibited uptake entirely (Fig. 6b), implying that the reductive pathway may play a role in FeDFB uptake by this organism. We also tested for the effect of the Fe(II)binding ligand BPDS on FeDFB uptake rate. Results were inconclusive (data not shown).

\section{DISCUSSION}

The most prominent result of our grow-out incubations is that the addition of different DFB concentrations induces a spectrum of iron limitations as the DFB titrates out naturally occurring iron in the Gulf waters. In accordance with this, 3 'iron status' regions can be identified in both the growth response ( $\Delta \mathrm{chl} a_{i}$ Fig. 3) and $F_{\mathrm{v}}: F_{\mathrm{m}}$ ratios (Fig. 4) of incubation communities.

Region 1 (natural Fe availability: $600 \mathrm{pM}$ to $3 \mathrm{nM}$ DFB) is characterized by a slight decrease in $\Delta$ chl a and $F_{\mathrm{v}}: F_{\mathrm{m}}$ values as compared to the nutrient-only control. Given the $\mathrm{Fe}_{\text {diss }}$ and $\mathrm{Fe}_{\text {total }}$ concentrations measured in the incubations $(3.5 \pm 1.3$ and $10.0 \pm$ $2.7 \mathrm{nM}$, respectively), this region may still have enough natural iron unbound to DFB to meet phytoplankton iron needs.

Region 2 (natural Fe titration by DFB: $3 \mathrm{nM}$ to $20 \mathrm{nM}$ DFB) is characterized by a sharp decrease in $\Delta \mathrm{chl} a$ and $F_{\mathrm{v}}: F_{\mathrm{m}}$ values as DFB concentration increases. The positive growth response (Fig. 3) suggests that FeDFB is bioavailable, and uptake experiments (Fig. 6a) reinforce this notion. Nonetheless, the bioavailability of FeDFB present at a maximum concentration of $\sim 10 \mathrm{nM}$ (the measured $\mathrm{Fe}_{\text {total }}$ in the incubation bottles) is too low to meet community iron demands, given the low $F_{\mathrm{v}}: F_{\mathrm{m}}$ values which are indicative of stress.

Region 3 (competition by excess DFB: $50 \mathrm{nM}$ to $1 \mu \mathrm{M})$ is characterized by negligible chl a increase and $F_{\mathrm{v}}: F_{\mathrm{m}}$ values are low. We propose that excess DFB further diminishes the already restricted accessibility of the FeDFB complex by competing with cells 
for unchelated iron formed at the cell surface by membrane reductases.

The ensuing discussion will further examine each of the regions defined above. The bioavailability of the FeDFB model complex will be compared to naturally occurring iron pools in the Gulf of Aqaba. We will discuss the dual nature of DFB as a model organic Feligand and as an iron limitation inducer. Finally, we will attempt to gauge the relevance of the Fe(II)s model to the uptake of organically bound iron by natural populations living in the Gulf as well as laboratory cultures of Synechococcus WH8102.

\section{Region 1. Natural Fe bioavailability}

Dissolved iron profiles in vast regions of the open ocean typically show nutrient-like depletion in surface waters (Martin \& Gordon 1988) and/or Fe minima correlating with chl a maxima (Bruland et al. 1991). In contrast, $\mathrm{Fe}_{\text {diss }}$ profiles from the Gulf of Aqaba (Fig. 2) show no evident Fe drawdown in the photic zone and no association with chl a profiles. This is not surprising since iron input from sediment and atmospheric sources is high (Chase et al. 2006, Shaked 2008) while phytoplankton demand is low. An estimated daily iron demand of $\sim 0.1 \mathrm{nM} \mathrm{d}^{-1}$ can be calculated by taking the rounded up cell counts at the beginning of our incubations of $\sim 2 \times 10^{5}$ cell ml-1 (including Synechococcus and picoeukaryotes), growth rates of $0.5 \mathrm{~d}^{-1}$ and an average cellular iron content of $1 \times 10^{-18} \mathrm{~mol} \mathrm{Fe} \mathrm{cell}{ }^{-1}$ (Sunda \& Huntsman 1995). It is most probable that the 3 to $4 \mathrm{nM} \mathrm{Fe} \mathrm{e}_{\text {diss }}$ measured in the Gulf of Aqaba during the spring season (Fig. 2) can support this demand. Thus, a priori, phytoplankton in the Gulf of Aqaba are not iron-limited. Physiological evidence to support this notion is the relatively high photochemical quantum efficiency values $\left(F_{\mathrm{v}}: F_{\mathrm{m}}: \sim 0.5\right)$ of the autotrophic community in nutrient-only controls, not indicative of any nutrient stress (Behrenfeld et al. 2006). In addition, when FeEDTA was added to collected seawater at the start of incubations, it did not elicit a growth response (Fig. 3). Similarly, nutrient enrichments conducted in the Gulf of Aqaba showed no further growth upon the addition of excess Fe (Chase et al. 2006).

Added insight into the bioavailability of iron in the Gulf can emerge from its physico-chemical speciation. Presently, we have no information on the identity and concentrations of iron-binding ligands in the Gulf. Thus, we assume minor organic complexation by humic and fluvic acids (no runoff in the arid study area) and by siderophores (culture based studies show negligible synthesis in Fe-replete community, Trick 1989). Colloidal iron is possibly an important constituent of the 'dissolved' $(<0.2 \mu \mathrm{m})$ iron pool, maintaining $\mathrm{Fe}$ concentrations high above the solubility limit $(\sim 0.7 \mathrm{nM}$, Byrne \& Kester 1976). The intensive photochemically driven iron redox recycling observed in the Gulf's surface waters (Shaked 2008) is likely to enhance the chemical reactivity and subsequently the dissolution rates of colloidal (and possibly particulate) iron which is not directly available to most phytoplankton (Rich \& Morel 1990).

\section{Region 2. Titration of natural Fe by DFB - FeDFB bioavailability}

All incubation carboys to which nutrients and DFB were added showed positive $\Delta \mathrm{chl}$ a values, i.e. a positive growth response (Fig. 3). Nonetheless, grow-out incubation data cannot be used to unambiguously prove FeDFB bioavailability since the observed growth may have been fueled by intracellular iron stores or may have originated from incomplete exchange between DFB and the natural iron pools (Wells \& Trick 2004). Both of these concerns are probably of minor importance in our relatively long ( 2 to $3 \mathrm{~d}$ ) incubations.

In any event, short-term uptake experiments with pre-complexed ${ }^{55} \mathrm{FeDFB}$ (Fig. 6a) explicitly prove that Fe-limited phytoplankton communities from the Gulf of Aqaba are capable of acquiring iron from the FeDFB complex. Since bulk, rather than size-fractionated uptake rates were measured for limited incubation populations, FeDFB uptake cannot be attributed to any one specific phytoplankton group. Nonetheless, based on the flow cytometry data from the $1 \mu \mathrm{M}$ DFB incubation carboys that were used for the uptake experiments (Fig. 5), it seems that Synechococcus was the dominant organism in our experiments.

While we do claim that the FeDFB complex is bioavailable, it is important to stress that natural populations from the Gulf of Aqaba were unable to acquire sufficient iron from FeDFB to meet their Fe needs. Incubation populations growing with DFB (>3 nM) were iron-limited when compared to nutrient-only controls as seen from smaller $\Delta \mathrm{chl} a$ and $F_{\mathrm{v}}: F_{\mathrm{m}}$ values (Figs. 3 \& 4). This limitation may be the result of low absolute FeDFB concentration (maximal [FeDFB] = $\left[\mathrm{Fe}_{\text {total }}\right]=10 \mathrm{nM}$ ) or low bioavailability of FeDFB possibly stemming from its very negative redox potential. Another facet of Fe-limitation in grow-out incubations is that the iron-replete cells from the Gulf may require sufficient acclimation time before they can access FeDFB. Iron-replete diatoms Thalassiosira oceanica and T .pseudonana (Maldonado \& Price 2001, Chen \& Wang 2008) have been shown to take up organically bound iron less readily than iron-starved cells. This has been put down to the activation of a high affinity uptake system under iron stress. 
The bioavailability of any Fe-ligand complex, be it FeDFB, FeEDTA or Fe-aerobactin, is influenced by an entire host of parameters such as the physiological status of the organisms, nature of the Fe-ligand and experimental design where things such as experiment length, Fe-ligand and free ligand concentrations can have a crucial impact on the outcome. These factors must be taken into account when comparing the uptake rates of different Fe-ligand complexes across various environments and organisms.

\section{Region 3. Competition by excess DFB - the reductive pathway}

The experimental results presented thus far clearly demonstrate the inhibitory effect of excess DFB: (1) a much lower chl a increase was observed in incubations containing $50 \mathrm{nM}$ and $1 \mu \mathrm{M}$ DFB as compared to those with lower DFB concentrations (600 pM to $20 \mathrm{nM}$; Fig. 3); (2) iron uptake was inhibited by over $70 \%$ in both field and culture uptake experiments upon the addition of $1 \mu \mathrm{M}$ DFB (Fig. 6). To rule out the possibility that inhibition was caused by something other than competition for reduced iron, we looked at 2 likely experimental artifacts that could also have an inhibitory effect: toxicity and change in Fe' concentrations. Inhibition due to DFB toxicity to cells was ruled out by the measuring of constant $F_{\mathrm{v}}: F_{\mathrm{m}}$ ratios over an $8 \mathrm{~h}$ incubation of Synechococcus WH8102 cultures supplemented with $1 \mu \mathrm{M}$ DFB (data not shown). As previously noted, DFB buffers extremely low unchelated iron $\left(\mathrm{Fe}^{\prime}\right)$, so low in fact that $\mathrm{Fe}^{\prime}$ can neither support phytoplankton growth nor have any real impact on short term Fe uptake. For example, an uptake rate of $\sim 4 \times 10^{-10} \mathrm{M} \mathrm{d}^{-1}$ measured in the presence of $\sim 50 \mathrm{nM}$ FeDFB, is 3 orders of magnitude greater than the rate at which $\mathrm{Fe}^{\prime}$ dissociate from FeDFB $\left(3 \times 10^{-13} \mathrm{M} \mathrm{d}^{-1}\right)$. Thus, a further decrease in Fe' concentrations when large excesses of DFB are added is not the cause of the observed decrease in uptake rate (Fig. 6). Fe' concentrations do play an important role, however, when interpreting uptake/growth inhibition by the addition of excess ligands such as EDTA or humic acid that have weaker binding constants than DFB (Shaked et al. 2005, Chen \& Wang 2008).

The recently published Fe(II)s model predicts that the inhibitory effect of any excess Fe-ligand, be it DFB or humic acid, stems from competition between excess ligand and the cells for Fe(II) formed at the cell surface (Shaked et al. 2005). While the Fe(II)s kinetic model cannot determine whether the excess ligand binds Fe(II) or $\mathrm{Fe}(\mathrm{III})$, chemical competition for unchelated iron in a FeDFB medium (which essentially contains no Fe') requires the formation of an intermediate iron species dur- ing the uptake process. We propose this intermediary to be Fe(II) formed by the extracellular reduction of the Feligand. This being said, it should be stated that the Fe(II)s model is based on eukaryotic organisms and caution must be taken in its application to gram negative bacteria such as Synechococcus spp. which have 2 membranes. The Fe(II)s model should thus be reevaluated with respect to gram-negative bacteria using a multi-approach combining a range of measurement techniques, organisms and organically bound Fe complexes.

\section{The reductive pathway: a broad spectrum Fe uptake mechanism?}

The extracellular reductive model has become an accepted archetype of eukaryotic iron-uptake (Morel et al. 2008). Prokaryotes, on the other hand, are thought to internalize the entire ferriligand complex and mediate the dissociation of Fe from the ligand in the periplasmic space or to access organically bound iron via a ligand exchange process at the cell surface (Armstrong et al. 2004 and references therein). It has been traditionally thought that since certain cyanobacterial strains produce siderophores (Wilhelm \& Trick 1994, Trick \& Wilhelm 1995), their uptake mechanism should be similar to that of other bacteria. To the best of our knowledge, no siderophores have been isolated from open ocean Synechococcus spp. Moreover, recent genetic studies (Webb et al. 2001) have identified some interesting absences in the predicted Fe-scavenging capabilities of open-ocean cyanobacteria. Not only could no known siderophore biosynthesis genes be identified in the genome of Synechococcus WH8102, but also no putative outer membrane receptor proteins for Fe siderophore complexes were found. This omission was also evident in open ocean cyanobacterium ProChlorococcus spp. strains MED4 and MIT9313 (Webb et al. 2001) and in the Cynaobacterium Trichodesmium spp. (K. L. Roe et al. unpubl.). A mechanism other than Fe-siderophore translocation through the outer membrane, as proposed for gram-negative bacteria, must therefore exist in these organisms. One such alternative-iron transport via a siderophore shuttle - was put forward by Stintzi et al. (2000). This uptake pathway involves adjunctive ligand substitution where iron is transferred from the ferric siderophore complex to a free siderophore bound to a cell surface receptor. It has been proposed to exist in heterotrophic and autotrophic marine bacteria, but no solid experimentation was carried out to assess its prevalence in the marine environment.

There is a fair chance that marine phytoplankton employ a variety of iron uptake strategies, similar to other well-studied organisms such as baker's yeast 
Saccharomyces cerevisiae (Eide 1997). Interestingly, while no siderophore associated system was described for Synechococcus WH8102 nor for other open ocean cyanobacterial strain (see above), a putative reductase gene in the marine cyanobacterium Trichodesmium spp. was recently reported (K. L. Roe et al. unpubl.). Here we present the novel possibility that Synechococcus spp. employ a reductive mechanism to access DFBbound iron. A broad spectrum reductive mechanism is a logical solution to cope with the heterogeneity of Fecomplexes in the ocean and could explain the reports of siderophore 'piracy' amongst marine microorganisms (Granger \& Price 1999). The question of prevalence and importance of the reductive pathway as a generalized mechanism that can be applied across a range of phytoplankton species and Fe-ligands in the marine environment is well worth revisiting in the hopes of finding a common denominator in the mechanisms of phytoplankton Fe-uptake.

Acknowledgements. A substantial part of this study was conducted during the 8th International Workshop of the Group for Aquatic Primary Productivity (GAP) and Batsheva de Rothschild Seminar on Gross and Net Primary Productivity, held at the Interuniversity Institute for Marine Sciences, Eilat, Israel, in April 2008. We thank M. Dray, N. Klein-Kedem, T. Rivlin, E. Cappuzzo and R. Burns of SAtlantic for their indispensable help. Thanks also to G. Yahel for his tireless help and advice in the FACS analysis. This work was supported in part by grant 2006192 from the United States-Israel Binational Science Foundation, Israel Science Foundation grant no 933/07 and the Moshe Shilo Center for Marine Biogeochemistry.

\section{LITERATURE CITED}

Al-Qutob M, Hase C, Tilzer MM, Lazar B (2002) Phytoplankton drives nitrite dynamics in the Gulf of Aqaba, Red Sea. Mar Ecol Prog Ser 239:233-239

Allnutt FCT, Bonner WDJ (1987a) Characterization of iron uptake from ferrioxamine B by Chlorella vulgaris. Plant Physiol 85:746-750

Armstrong E, Granger J, Mann EL, Price NM (2004) Outermembrane siderophore receptors of heterotrophic oceanic bacteria. Limnol Oceanogr 49:579-587

Barbeau K (2006) Photochemistry of organic iron(III) complexing ligands in oceanic systems. Photochem Photobiol 82:1505-1516

Behrenfeld MJ, Kolber ZS (1999) Widespread iron limitation of phytoplankton in the South Pacific Ocean. Science 283: 840-843

Behrenfeld MJ, Worthington K, Sherrell RM, Chavez FP, Strutton P, McPhaden M, Shea DM (2006) Controls on tropical Pacific Ocean productivity revealed through nutrient stress diagnostics. Nature 442:1025-1028

Ben-Sasson M, Brenner S, Paldor N (2009) Estimating air-sea heat fluxes in semi-enclosed basins: the case of the Gulf of Elat (Aqaba). J Phys Oceanogr 39:185-202

Bruland KW, Donat JR, Hutchins DA (1991) Interactive influences of bioactive trace metals on biological production in oceanic waters. Limnol Oceanogr 36:1555-1577
Byrne RH, Kester DR (1976) Solubility of hydrous ferric oxide and iron speciation in seawater. Mar Chem 4:255-274

Chase Z, Paytan A, Johnson KS, Street J, Chen Y (2006) Input and cycling of iron in the Gulf of Aqaba, Red Sea. Global Biogeochem Cycles 20(3), GN3017, doi:10.1029/ 2005GB002646

Chen M, Wang WX (2008) Accelerated uptake by phytoplankton of iron bound to humic acids. Aquat Biol 3: 155-166

Duke CS, Cezeaux A, Allen MM (1989) Changes in polypeptide composition of Synechocystis sp. strain 6308 phycobilisomes induced by nitrogen starvation. J Bacteriol 171: 1960-1966

> Eide D (1997) Molecular biology of iron and zinc uptake in eukaryotes. Curr Opin Cell Biol 9:573-577

> Eldridge ML, Trick CG, Alm MB, DiTullio GR and others (2004) Phytoplankton community response to a manipulation of bioavailable iron in HNLC waters of the subtropical Pacific Ocean. Aquat Microb Ecol 35:79-91

> Genin A, Lazar B, Brenner S (1995) Vertical mixing and coral death in the Red Sea following the eruption of Mount Pinatubo. Nature 377:507-510

Granger J, Price NM (1999) The importance of sidrophores in iron nutrition of hetrotrophic marine bacteria. Limnol Oceanogr 44:541-555

Hansen HP, Koroleff F (1999) Determination of nutrients. In: Grasshoff K, Kremling K, Ehrhardt M (eds) Methods of seawater analysis. Verlag Chemie, Weinheim, p 159-228

Hudson RJM, Morel FMM (1989) Distinguishing between extracellular and intracellular iron in marine phytoplankton. Limnol Oceanogr 34:1113-1120

Hudson RJM, Morel FMM (1990) Iron transport in marine phytoplankton: kinetics of cellular and medium coordination reactions. Limnol Oceanogr 35:1002-1020

> Hudson RJM, Covault DT, Morel FMM (1992) Investigations of iron coordination and redox reactions in seawater using ${ }^{59} \mathrm{Fe}$ radiometry and ion-pair solvent extraction of amphiphilic iron complexes. Mar Chem 38:209-235

Labiosa RG, Arrigo KR, Genin A, Monismith SG, van Dijken G (2003) The interplay between upwelling and deep convective mixing in determining the seasonal phytoplankton dynamics in the Gulf of Aqaba: evidence from SeaWiFS and MODIS. Limnol Oceanogr 48:2355-2368

> Lannuzel D, de Jong J, Schoemann V, Trevena A, Tison JL, Chou L (2006) Development of a sampling and flow injection analysis technique for iron determination in the sea ice environment. Anal Chim Acta 556:476-483

Lindell D, Post AF (1995) Ultraphytoplankton succession is triggered by deep winter mixing in the Gulf of Aqaba (Eilat), Red Sea. Limnol Oceanogr 40:1130-1141

> Maldonado M, Price NM (2001) Reduction and transport of organically bound iron by Thalassiosira oceanica (Bacillariophyceae). J Phycol 37:298-309

> Marie D, Partensky F, Jacquet S, Vaulot D (1997) Enumeration and cell cycle analysis of natural populations of marine picoplankton by flow cytometry using the nucleic acid stain SYBR Green I. Appl Environ Microbiol 63: 186-193

Martin JH, Gordon RM (1988) Northeast Pacific iron distributions in relation to phytoplankton productivity. Deep-Sea Res 35:177-196

> Martin JH, Gordon RM, Fitzwater SE (1990) Iron in Antarctic waters. Nature 345:156

Martinez JS, Haygood MG, Butler A (2001) Identification of a natural desferrioxamine siderophore produced by a marine bacterium. Limnol Oceanogr 46:420-424 
Mawji E, Gledhill M, Milton JA, Tarran GA and others (2008) Hydroxamate siderophores: occurence and importance in the Atlantic Ocean. Environ Sci Technol 42:8675-8680

Moore LR, Coe A, Zinser ER, Saito MA and others (2007) Culturing the marine cyanobacterium Prochlorococcus. Limnol Oceanogr Methods 5:353-362

Morel FMM, Rueter JG, Anderson DM, Guillard RR (1979) Aquil: a chemically defined phytoplankton culture medium for trace metal studies. J Phycol 15:135-141

Morel FMM, Kustka AB, Shaked Y (2008) The role of unchelated $\mathrm{Fe}$ in the iron nutrition of phytoplankton. Limnol Oceanogr 43:400-404

Parsons TR, Maita Y, Lalli CM (1985) Manual of chemical and biological methods for seawater analysis. Pergamon, Oxford

Partensky F, Blanchot J, Lantoine F, Neveux J, Marie D (1996) Vertical structure of picophytoplankton at different trophic sites of the tropical northeastern Atlantic Ocean. Deep-Sea Res I 43:1191-1213

Penno S, Lindell D, Post AF (2006) Diversity of Synechococcus and Prochlorococcus populations determined from DNA sequences of the N-regulatory gene ntcA. Environ Microbiol 8:1200-1211

Rich HW, Morel FMM (1990) Availability of well-defined iron colloids to the marine diatom Thalassiosira weissflogii. Limnol Oceanogr 35:652-662

Rue EL, Bruland KW (1995) Complexation of iron(III) by natural organic ligands in the Central North Pacific as determined by a new competitive ligand equilibration/adsorptive cathodic stripping voltammetric method. Mar Chem 50:117

Shaked Y (2008) Iron redox dynamics in the surface waters of the Gulf of Aqaba, Red Sea. Geochim Cosmochim Acta 72:1540-1554

Shaked Y, Kustka AB, Morel FMM (2005) A general kinetic model for iron acquisition by eukaryotic phytoplankton. Limnol Oceanogr 50:872-882

Sommer U, Berninger UG, Boettger-Schnack R, Cornils A and others (2002) Grazing during early spring in the Gulf of Aqaba and the northern Red Sea. Mar Ecol Prog Ser 239:251-261

Soria-Dengg S, Horstmann U (1995) Ferrioxamines B and E as iron sources for the marine diatom Phaeodactylum tricornutum. Mar Ecol Prog Ser 127:269-277

Editorial responsibility: Hugh McIntyre,

Dauphin Island, Alabama, USA
Stintzi A, Barnes C, Xu L, Raymond KN (2000) Microbial iron transport via a siderophore shuttle: a membrane ion transport paradigm. Proc Natl Acad Sci USA 97:10691-10696

Suggett DJ, Stambler N, Prášil O, Kolber Z and others (2009) Nitrogen and pgosphorus limitation of oceanic microbial growth during spring in the Gulf of Aqaba. Aquat Microb Ecol 56:227-239

Sunda WG, Huntsman SA (1995) Iron uptake and growth limitation in oceanic and coastal phytoplankton. Mar Chem 50:189-206

Trick CG (1989) Hydroxamate-siderophore production and utilization by marine eubacteria. Curr Microbiol 18: 375-378

- Trick CG, Wilhelm SW (1995) Physiological changes in the coastal marine cyanobacterium Synechococcus sp. PCC 7002 exposed to low ferric ion levels. Mar Chem 50: $207-217$

Vaulot D (1989) CYTOPC: processing software for flow cytometric data. Signal Noise 2:8

> Webb EA, Moffett JW, Waterbury JB (2001) Iron stress in open-ocean cyanobacteria (Synechococcus, Trichodesmium, and Crocosphaera spp.): identification of the IdiA protein. Appl Environ Microbiol 67:5444-5452

Wells ML (1999) Manipulating iron availability in nearshore waters. Limnol Oceanogr 44:1002-1008

Wells ML, Trick CG (2004) Controlling iron availability to phytoplankton in iron-replete coastal waters. Mar Chem 86:1-13

Wells ML, Price NM, Bruland KW (1994) Iron limitation and the cyanobacterium Synechococcus in equatorial Pacific waters. Limnol Oceanogr 39:1481-1486

Wilhelm SW, Trick CG (1994) Iron-limited growth of cyanobacteria: multiple siderophore production is a common response. Limnol Oceanogr 39:1979-1984

Winkelmann G (1991) Specificity of iron transport in bacteria and fungi. In: Winkelmann G (ed) Handbook of microbial iron chelates. CRC Press, Boca Raton, FL, p 65-106

Winkelmann G (2002) Microbial siderophore-mediated transport. Biochem Soc Trans 30:691-696

Yahel G, Sharp JH, Marie D, Häse C, Genin A (2003) In situ feeding and element removal in the coral-reef sponge Theonella swinhoei: bulk DOC is the major source for carbon. Limnol Oceanogr 48:141-149

Submitted: December 4, 2008; Accepted: June 27, 2009

Proofs received from author(s): August 12, 2009 